\title{
ANTIBIOTIC RESISTANCE IN STAPHYLOCOCCUS AUREUS ISOLATED AT AN AUSTRALIAN HOSPITAL BETWEEN
} 1946 AND 1981

\author{
M. T. Gillespie, J. W. May and R. A. Skurray* \\ Microbiology Department, Monash University, Clayton, Victoria, Australia 3168
}

\begin{abstract}
Summary. A total of 517 strains of Staphylococcus aureus isolated at a hospital in Melbourne, Australia between 1946 and 1981 was examined for resistance to a range of antimicrobial agents and for the presence of plasmid DNA. The use of mixed-culture transfer and restriction endonuclease analysis showed that the determinants for resistance to penicillin and to the heavy metals were carried by several related plasmids of $(15-23) \times 10^{6} \mathrm{~mol}$. wt, and that tetracycline resistance was encoded on a plasmid of $2.8 \times 10^{6} \mathrm{~mol}$. wt in strains isolated before 1970 . These phenotypes were chromosomally encoded in the majority of strains isolated thereafter. Resistance to chloramphenicol throughout the study period was plasmid-mediated. Of five aminoglycoside-resistance phenotypes, one was plasmid-mediated and three were chromosomally encoded. The remaining phenotype, specifying low-level gentamicin resistance, was found to be located on the chromosome of early isolates, but in later strains was borne by an $18 \times 10^{6} \mathrm{~mol}$. wt plasmid which also encoded resistance to quaternary ammonium compounds.
\end{abstract}

\section{INTRODUCTION}

Multiresistant Staphylococcus aureus have been important pathogens in Melbourne hospitals during recent years (Pavillard et al., 1982). Molecular analysis of plasmid DNA isolated from such strains of $S$. aureus has identified separate plasmids encoding resistance to chloramphenicol and gentamicin (Lyon, May and Skurray, 1983; Townsend, Grubb and Ashdown, 1983a; Lyon et al., 1984a; Tennent, May and Skurray, 1984), although the latter resistance is chromosomally encoded in some strains. Resistance to erythromycin, kanamycin-neomycin, penicillin, streptomycin, tetracycline, cadmium and mercury is usually mediated by determinants carried by the chromosome in these multiresistant $S$. aureus strains (Lyon et al., 1983, 1984a). In contrast, a study of methicillin-resistant $S$. aureus strains isolated between 1969 and 1981 from a Melbourne hospital (Gillespie, May and Skurray, 1984), revealed that the determinants for penicillinase production and resistance to the heavy metals and tetracycline were plasmid-borne in strains isolated in 1969.

Received 26 Jun. 1984; accepted 5 Jul. 1984.

*Correspondence and reprint requests should be sent to Dr R. A. Skurray. 
Although the bacteriophage types of Australian strains of $S$. aureus isolated from the late 1940s to mid 1970s have been well documented (Rountree, Barbour and Thomson, 1951; Rountree, 1953 and 1978; Rountree and Beard, 1958 and 1965; Rountree and Vickery, 1973), little information is available about the plasmids present in $S$. aureus strains before the onset of methicillin resistance. This paper reviews the antibiotic-resistance patterns and plasmid-DNA profiles of clinical isolates of $S$. aureus isolated in a Melbourne hospital during four decades of antibiotic therapy.

\section{MATERIALS AND METHODS}

Staphylococcus aureus strains. Clinical isolates of $S$. aureus were collected, identified and stored vacuum-dried in ampoules at the Bacteriology Department, Alfred Hospital, Melbourne and subsequently made available to this laboratory.

S. aureus strains RN2424 and RN2442, carrying the plasmids pT181 and pE194 (Novick et al., 1980) respectively, were kindly provided by R. P. Novick (Public Health Research Institute of the City of New York). Strain SK982, the restriction-deficient recipient strain employed in mixed culture transfers, carries chromosomal resistance to novobiocin and rifampicin and was constructed in this laboratory (Lyon, May and Skurray, 1984b).

General procedures. L-broth and L-agar media, methods for determination of penicillinase production, minimum inhibitory concentrations, antibiotic and heavy metal resistance and plasmid elimination procedures were as described previously (Lyon et al., 1983; Gillespie et al., 1984). Resistance to the quaternary ammonium compounds benzalkonium chloride (Sigma Chemical Company, St Louis, MO 63178 USA) and cetyltrimethylammonium bromide (BDH Chemicals Ltd, Poole, England) was tested in L-agar at concentrations of 4 and $2 \mathrm{mg} / \mathrm{L}$, respectively. Mixed culture transfer by the method of McDonnell, Sweeney and Cohen (1983) was used to transfer resistance to strain SK982.

Plasmid DNA isolation and restriction endonuclease analysis. DNA was isolated by a rapid procedure and analysed by electrophoresis on $1.0 \%$ Tris-acetate-EDTA buffered agarose horizontal gels with standard plasmids of known mol. wt as previously described (Lyon et al., 1983). Preparation of caesium chloride-ethidium bromide purified plasmid DNA and restriction endonuclease analysis with EcoRI (Boehringer-Mannheim Australia Pty Ltd, North Ryde, 2113), Hind III, MboI and TaqI (New England Biolabs, Beverly, MA 01915, USA) were as reported previously (Lyon et al., 1983).

\section{RESULTS}

\section{Characteristics of $S$. aureus isolates}

The percentages of isolates resistant to various antimicrobial agents in each year of the study are presented in table $\mathrm{I} ;<6 \%$ of the total were susceptible to all agents tested. The majority were resistant to penicillin, streptomycin, arsenate, arsenite, cadmium and mercury; resistance to rifampicin and vancomycin was not encountered. During the late 1940s, penicillin- and streptomycin-resistant $S$. aureus were noted and by early 1951 tetracycline or chloramphenicol resistance or both in conjunction with penicillin, streptomycin, arsenate, arsenite, cadmium and mercury resistance was encountered in some isolates. It is interesting to note that resistance to fusidic acid was detected in this period well before clinical use of this agent. Kanamycin- and neomycin-resistant $\left(\mathrm{KN}^{\mathrm{R}}\right)$ strains were first observed in 1965 , with some of these strains being additionally resistant to tobramycin $\left(\mathrm{TKN}^{\mathrm{R}}\right)$; the latter phenotype was not encountered again until 1980. Methicillin resistance was also first observed at this hospital in 1965.

Minimum inhibitory concentrations (MIC) of aminoglycoside antibiotics for these 
TABLE I

Antibiotic susceptibilities of S. aureus

\begin{tabular}{|c|c|c|c|c|c|c|c|c|c|c|c|c|c|c|c|c|c|c|c|}
\hline \multirow{2}{*}{$\begin{array}{l}\text { Year of } \\
\text { isolation }\end{array}$} & \multirow{2}{*}{$\begin{array}{c}\text { Number of } \\
\text { isolates }\end{array}$} & \multirow{2}{*}{$\begin{array}{l}\text { Percentage } \\
\text { of sensitive } \\
\text { isolates }\end{array}$} & \multicolumn{17}{|c|}{ Percentage of isolates resistant to } \\
\hline & & & Pc & $\mathrm{Mc}$ & $\mathrm{Sm}$ & $\mathrm{Tc}$ & $\mathrm{Em}$ & $\mathrm{Cl}$ & $\mathrm{Cm}$ & $\mathrm{Gm}$ & $\operatorname{Tm}$ & $\mathrm{Km}$ & $\mathrm{Nm}$ & Ak & $\mathrm{Fa}$ & Asa & Asi & $\mathrm{Cd}$ & $\mathrm{Hg}$ \\
\hline 1946 & 7 & 0 & 0 & 0 & 14 & 0 & 0 & 0 & 0 & 0 & 0 & 0 & 0 & 0 & 0 & 57 & 57 & 85 & 14 \\
\hline 1947 & 22 & 27 & 13 & 0 & 5 & 0 & 0 & 0 & 0 & 0 & 0 & 0 & 0 & 0 & 5 & 55 & 55 & 73 & 37 \\
\hline 1948 & 1 & 0 & 0 & 0 & 0 & 0 & 0 & 0 & 0 & 0 & 0 & 0 & 0 & 0 & 0 & 100 & 100 & 100 & 0 \\
\hline 1949 & 6 & 0 & 83 & 0 & 33 & 0 & 0 & 0 & 0 & 0 & 0 & 0 & 0 & 0 & 0 & 17 & 17 & 100 & 0 \\
\hline 1950 & 10 & 10 & 20 & 0 & 40 & 0 & 0 & 0 & 0 & 0 & 0 & 0 & 0 & 0 & 0 & 90 & 90 & 80 & 60 \\
\hline 1951 & 117 & 6 & 36 & 0 & 58 & 3 & 0 & 0 & 2 & 0 & 0 & 0 & 0 & 0 & 3 & 60 & 60 & 85 & 50 \\
\hline 1952 & 129 & 7 & 47 & 0 & 53 & 9 & 0 & 0 & 9 & 0 & 0 & 0 & 0 & 0 & 2 & 70 & 70 & 85 & 83 \\
\hline 1953 & 17 & 0 & 41 & 0 & 53 & 6 & 0 & 0 & 6 & 0 & 0 & 0 & 0 & 0 & 0 & 53 & 53 & 83 & 35 \\
\hline 1954 & 1 & 0 & 0 & 0 & 0 & 0 & 0 & 0 & 0 & 0 & 0 & 0 & 0 & 0 & 0 & 0 & 0 & 100 & 100 \\
\hline 1957 & 3 & 0 & 0 & 0 & 67 & 0 & 0 & 0 & 0 & 0 & 0 & 0 & 0 & 0 & 0 & 67 & 67 & 67 & 0 \\
\hline 1960 & 9 & 11 & 67 & 0 & 44 & 55 & 0 & 0 & 0 & 0 & 0 & 0 & 0 & 0 & 0 & 67 & 67 & 78 & 78 \\
\hline 1961 & 5 & 0 & 60 & 0 & 40 & 40 & 0 & 0 & 20 & 0 & 0 & 0 & 0 & 0 & 0 & 100 & 100 & 100 & 100 \\
\hline 1962 & 8 & 63 & 0 & 0 & 13 & 13 & 13 & 0 & 13 & 0 & 0 & 0 & 0 & 0 & 0 & 13 & 13 & 25 & 13 \\
\hline 1963 & 1 & 0 & 100 & 0 & 100 & 100 & 0 & 0 & 0 & 0 & 0 & 0 & 0 & 0 & 0 & 100 & 100 & 100 & 0 \\
\hline 1964 & 2 & 0 & 50 & 0 & 0 & 0 & 0 & 0 & 0 & 0 & 0 & 0 & 0 & 0 & 0 & 50 & 50 & 100 & 50 \\
\hline 1965 & 116 & 1 & 86 & 6 & 73 & 78 & 64 & 10 & 18 & 0 & 4 & 22 & 22 & 0 & 0 & 84 & 84 & 91 & 69 \\
\hline 1966 & 20 & 0 & 85 & 0 & 95 & 85 & 70 & 30 & 20 & 0 & 0 & 90 & 90 & 0 & 0 & 70 & 70 & 80 & 65 \\
\hline 1967 & 26 & 0 & 96 & 19 & 81 & 23 & 8 & 8 & 12 & 0 & 0 & 8 & 8 & 0 & 0 & 89 & 89 & 100 & 100 \\
\hline 1968 & 4 & 0 & 100 & 0 & 75 & 75 & 0 & 0 & 25 & 0 & 0 & 0 & 0 & 0 & 0 & 50 & 50 & 75 & 25 \\
\hline 1971 & 1 & 0 & 0 & 0 & 0 & 0 & 0 & 0 & 0 & 0 & 0 & 0 & 0 & 0 & 0 & 100 & 100 & 100 & 0 \\
\hline 1973 & 2 & 0 & 100 & 50 & 100 & 50 & 50 & 50 & 0 & 0 & 0 & 50 & 50 & 0 & 0 & 50 & 50 & 100 & 100 \\
\hline 1976 & 3 & 0 & 100 & 100 & 100 & 100 & 100 & 100 & 0 & 100 & 100 & 100 & 100 & 0 & 0 & 0 & 0 & 0 & 0 \\
\hline 1980 & 1 & 0 & 0 & 0 & 0 & 0 & 0 & 0 & 0 & 0 & 100 & 100 & 100 & 0 & 0 & 0 & 0 & 0 & 0 \\
\hline 1981 & 6 & 0 & 100 & 83 & 83 & 100 & 83 & 83 & 50 & 50 & 50 & 50 & 17 & 17 & 0 & 0 & 0 & 67 & 50 \\
\hline
\end{tabular}

Pc, penicillin; Mc, methicillin; Sm, streptomycin; Tc, tetracycline; Em, erythromycin; Cl, clindamycin; Cm, chloramphenicol; Gm, gentamicin; Tm, tobramycin; Km, kanamycin; Nm, neomycin; Ak, amikacin; Fa, fusidic acid; Asa, arsenate; Asi, arsenite; Cd, cadmium; Hg, mercury.

strains revealed two distinct levels of gentamicin resistance. Strains resistant to gentamicin, tobramycin, kanamycin and neomycin $\left(\mathrm{GTKN}^{\mathrm{R}}\right)$, such as the 1976 isolates, or to gentamicin, tobramycin and kanamycin $\left(\mathrm{GTK}^{\mathrm{R}}\right)$ displayed low-level gentamicin resistance $(128 \mathrm{mg} / \mathrm{L})$. Only one isolate in this collection, SK 460 from 1981 , displayed high-level gentamicin resistance $(>4096 \mathrm{mg} / \mathrm{L}$ ) and was additionally resistant to tobramycin, kanamycin, neomycin and amikacin $\left(G_{T K N A}{ }^{\mathrm{R}}\right)$; SK460 has been described previously (Lyon et al., 1984a). The aminoglycoside MICs for GTK ${ }^{\mathrm{R}}$, GTKN $^{\mathrm{R}}$ and GTKNA ${ }^{\mathrm{R}}$ strains in this study were equivalent to those displayed by strains of similar phenotypes isolated from another Melbourne hospital (Gillespie et al., 1984). The MICs of tobramycin, kanamycin and neomycin for $\mathrm{TKN}^{\mathrm{R}}$ strains were 64,64 and $128 \mathrm{mg} / \mathrm{L}$, respectively.

Among the strains that were bacteriophage typed, group I, II, III and mixed group I/III lytic patterns were represented; the majority of strains were either group III or non-typable. The bacteriophage types and antibiotic-resistance phenotypes of 16 selected isolates from the period 1947 to 1981 are presented in table II.

\section{Plasmid composition of $S$. aureus and location of resistance determinants}

A total of 206 isolates was screened for the presence of plasmid DNA; fig. 1 shows the agarose-gel electrophoresis of DNA isolated from the representative strains in table II. The use of mixed culture transfer and plasmid elimination procedures permitted the identification of a number of plasmid-encoded phenotypes. The 


\section{$a b c d e f g h$ i j k Imnopq}

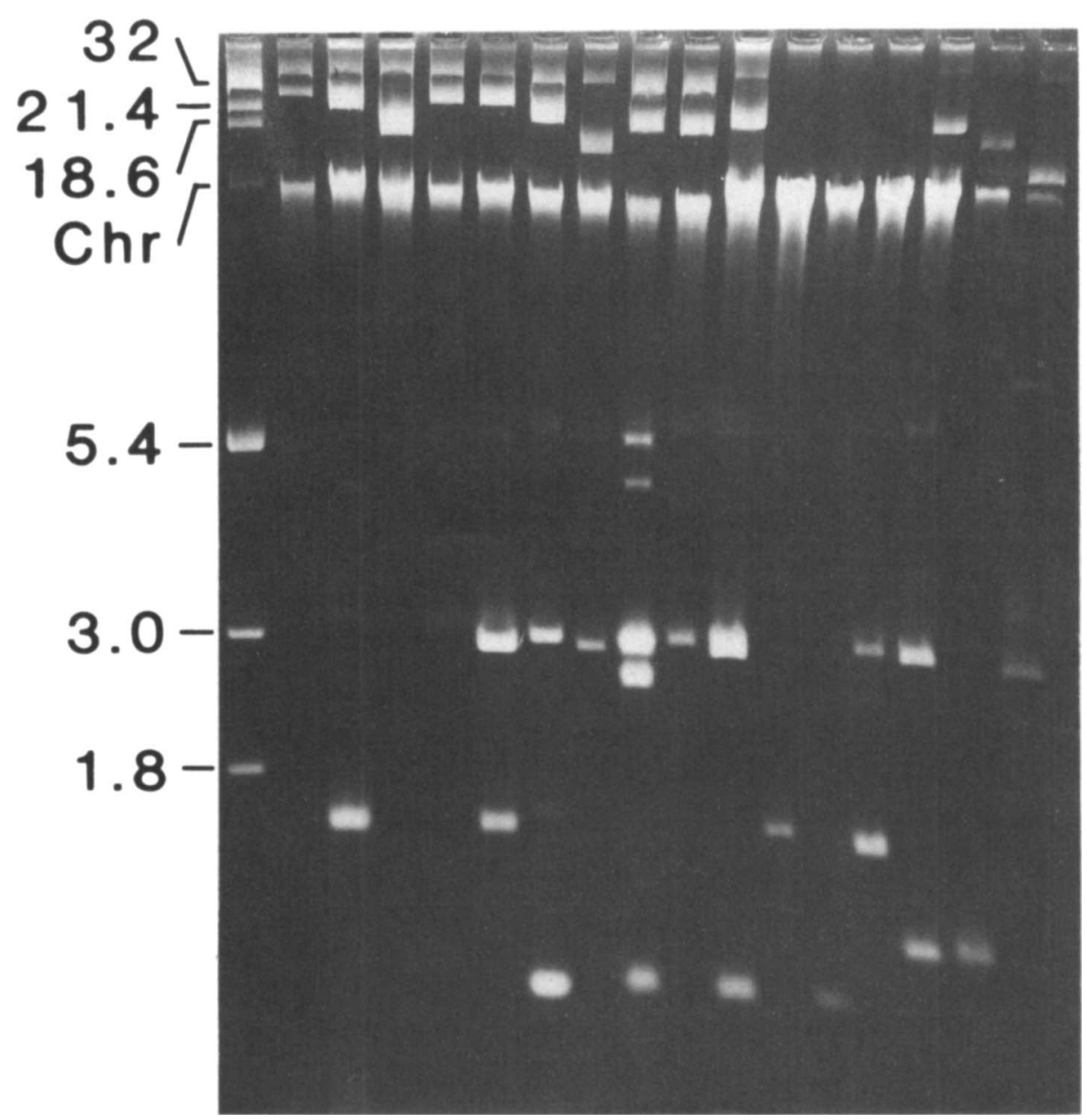

FIG. 1.-Agarose gel $(1.0 \% \mathrm{w} / \mathrm{v})$ electrophoresis of rapidly isolated $S$. aureus DNA. The chromosomal band is labelled Chr. Lanes contain: (a) molecular weight standards with sizes $\left(10^{6}\right)$ shown on the left; (b) SK1011; (c) SK1020; (d) SK1027; (e) SK1073; (f) SK1215; (g) SK1064; (h) SK1373; (i) SK1396; (j) SK 1499; (k) SK 1529; (l) SK1585; (m) SK 1582; (n) SK 1597; (o) SK462; (p) SK460; and (q) SK 1592. Characteristics of these strains are presented in table II; their order across the gel corresponds to that down the table.

plasmids detected in this study, along with the resistance phenotypes which they confer and their sizes, are summarised in table III.

The plasmids pSK60 (SK 1011), pSK75 (SK 1073), pSK79 (SK1215), pSK74 (SK 1064), pSK76 (SK1373) and pSK80 (SK 1529) (fig. 1, lanes b, e, f, g, h and k) encode resistance to the heavy metals arsenate, arsenite, cadmium and mercury and carry the determinants for penicillinase production. Plasmids pSK64 (SK 1020) and pSK59 (SK1396) (fig. 1, lanes c and i), also mediate resistance to these four heavy metals but not to penicillin, while the plasmids pSK67 (SK1027; fig. 1, lane d) and 
TABLE II

Characteristics of selected $S$. aureus strains

\begin{tabular}{|c|c|c|c|c|}
\hline $\begin{array}{l}\text { Year of } \\
\text { isolation }\end{array}$ & $\begin{array}{c}\text { Strain } \\
\text { number }\end{array}$ & Resistance to* & $\begin{array}{l}\text { Penicillinase } \\
\text { production }\end{array}$ & Bacteriophage type $\uparrow$ \\
\hline 1947 & SK 1011 & Pc, Asa, Asi, Cd, Hg & + & $83 \mathrm{~A}$ \\
\hline 1947 & SK 1020 & Asa, Asi, Cd, $\mathrm{Hg}$ & - & $\begin{array}{l}52 / 52 \mathrm{~A} / 79 / 80 / 81 / 6 / 42 \mathrm{E} / 47 / \\
53 / 54 / 75 / 77 / 83 \mathrm{~A} / 85\end{array}$ \\
\hline 1949 & SK 1027 & $\mathrm{Pc}, \mathrm{Cd}$ & + & $42 \mathrm{E} / 47 / 53 / 54 / 75 / 77 / 83 \mathrm{~A}$ \\
\hline 1951 & SK 1073 & Pc, Asa, Asi, Cd, Hg & + & $75 / 77 / 85$ \\
\hline 1953 & SK 1215 & Pc, Sm, Tc, Asa, Asi, Cd, Hg & + & $6 / 47 / 85$ \\
\hline 1953 & SK 1064 & Pc, Sm, Tc, Asa, Asi, Cd, Hg & + & $53 / 54 / 75 / 77$ \\
\hline 1960 & SK 1373 & $\mathrm{Pc}, \mathrm{Sm}, \mathrm{Cm}, \mathrm{Asa}, \mathrm{Asi}, \mathrm{Cd}, \mathrm{Hg}$ & + & $80 / 81$ \\
\hline 1965 & SK 1396 & Sm, Tc, Em, Cm, Asa, Asi, Cd, $\mathrm{Hg}$ & - & $42 \mathrm{E} / 47 / 53 / 54 / 75 / 77 / 84$ \\
\hline 1965 & SK 1499 & $\mathrm{Pc}, \mathrm{Sm}, \mathrm{Tm}, \mathrm{Km}, \mathrm{Nm}, \mathrm{Cd}$ & + & $95 ; 100$ RTD \\
\hline 1965 & SK 1529 & Pc, Mc, Sm, Tc, Em, Asa, Asi, Cd, Hg & + & $77 / 84 / 85 ; 100$ RTD \\
\hline 1973 & SK 1585 & $\mathrm{Pc}, \mathrm{Mc}, \mathrm{Sm}, \mathrm{Tc}, \mathrm{Em}, \mathrm{Cl}, \mathrm{Km}, \mathrm{Nm}, \mathrm{Cd}, \mathrm{Hg}$ & + & NT \\
\hline 1976 & SK 1582 & $\mathrm{Pc}, \mathrm{Mc}, \mathrm{Sm}, \mathrm{Tc}, \mathrm{Em}, \mathrm{Cl}, \mathrm{Gm}, \mathrm{Tm}, \mathrm{Km}, \mathrm{Nm}$ & + & NT \\
\hline 1980 & SK 1597 & $\mathrm{Tm}, \mathrm{Km}, \mathrm{Nm}$ & - & 47 \\
\hline 1981 & SK 462 & $\begin{array}{l}\mathrm{Pc}, \mathrm{Mc}, \mathrm{Sm}, \mathrm{Tc}, \mathrm{Em}, \mathrm{Cl}, \mathrm{Cm}, \mathrm{Gm}, \mathrm{Tm}, \mathrm{Km}, \\
\mathrm{Cd}, \mathrm{Hg}, \mathrm{Eb}, \mathrm{Qa}\end{array}$ & + & $83 \mathrm{~A} / 85$ \\
\hline 1981 & SK460 & $\begin{array}{l}\mathrm{Pc}, \mathrm{Mc}, \mathrm{Sm}, \mathrm{Tc}, \mathrm{Em}, \mathrm{Cl}, \mathrm{Cm}, \mathrm{Gm}, \mathrm{Tm}, \mathrm{Km} \text {, } \\
\quad \mathrm{Nm}, \mathrm{Ak}, \mathrm{Cd}, \mathrm{Hg}, \mathrm{Eb}, \mathrm{Oa}\end{array}$ & + & $83 \mathrm{~A} ; 100 \mathrm{RTD}$ \\
\hline 1981 & SK 1592 & $\mathrm{Pc}, \mathrm{Sm}, \mathrm{Tc}, \mathrm{Cm}, \mathrm{Cd}$ & + & $53 / 54 / 85 / 90$ \\
\hline
\end{tabular}

*Abbreviations as in table 1 , with the addition of $\mathrm{Eb}=$ ethidium bromide; $\mathrm{Q} a=$ quaternary ammonium compounds.

$\dagger$ Unless otherwise indicated, bacteriophage types were determined at routine test dilution (RTD); NT = not typable at either RTD or 100 RTD.

TABLE III

Properties of plasmids detected in S. aureus

\begin{tabular}{|c|c|c|c|c|}
\hline Plasmid & $\begin{array}{c}\text { Isolate } \\
\text { no. }\end{array}$ & $\begin{array}{l}\text { Resistance } \\
\text { phenotype }\end{array}$ & $\begin{array}{c}\text { Size } \\
\left(\mathrm{mol} . \mathrm{wt} \times 10^{6}\right)\end{array}$ & $\begin{array}{l}\text { Year } \\
\text { detected }\end{array}$ \\
\hline pSK1 & SK462 & $\mathrm{Gm}^{\mathrm{R}} \mathrm{Tm}^{\mathrm{R}} \mathrm{Km}^{\mathrm{R}} \mathrm{Eb}^{\mathrm{R}} \mathrm{Qa}^{\mathrm{R}}$ & $18 \cdot 0$ & 1981 \\
\hline pSK2 & SK 462 & $\mathrm{Cm}^{\mathrm{R}}$ & $3 \cdot 0$ & 1981 \\
\hline pSK 7 & SK 460 & $\mathrm{~Eb}^{\mathrm{R}} \mathrm{Qa}^{\mathrm{R}}$ & 15.0 & 1981 \\
\hline pSK 50 & SK1597 & $\operatorname{Tm}_{\mathrm{R}}^{\mathrm{R}} \mathrm{Km}^{\mathrm{R}} \mathrm{Nm}^{\mathrm{R}}$ & $3 \cdot 0$ & 1980 \\
\hline $\mathrm{K} 52$ & SK 1215 & $\mathrm{Tc}^{\mathrm{R}}$ & $2 \cdot 8$ & 1953 \\
\hline pSK 59 & SK 1396 & Asa ${ }^{R} \mathrm{Asi}^{\mathrm{R}} \mathrm{Cd}^{\mathrm{R}} \mathrm{Hg}^{\mathrm{R}}$ & 18.9 & 1965 \\
\hline pSK 60 & SK1011 & $\mathrm{Pc}^{\mathrm{R}} \mathrm{Asa}^{\mathrm{R}} \mathrm{Asi}^{\mathrm{R}} \mathrm{Cd}^{\mathrm{R}} \mathrm{Hg}^{\mathrm{R}}$ & $22 \cdot 7$ & 1947 \\
\hline pSK61 & SK 1396 & $\mathrm{Em}^{\mathrm{R}}$ & $2 \cdot 4$ & 1965 \\
\hline pSK64 & SK 1020 & $\mathrm{Asa}^{\mathrm{R}} \mathrm{Asi}^{\mathrm{R}} \mathrm{Cd}^{\mathrm{R}} \mathrm{Hg}^{\mathrm{R}}$ & $22 \cdot 5$ & 1947 \\
\hline pSK 67 & SK 1027 & $\mathrm{Pc}^{\mathrm{R}} \mathrm{Cd}^{\mathrm{R}}$ & 17.0 & 1949 \\
\hline $\mathrm{K} 68$ & SK 1592 & $\mathrm{Cm}^{\mathrm{R}} \mathrm{Sm}^{\mathrm{R}}$ & $3 \cdot 0$ & 1981 \\
\hline $\mathrm{K} 70$ & SK 1064 & $\mathrm{Cm}^{\mathrm{R}}$ & $3 \cdot 0$ & 1953 \\
\hline K71 & SK 1396 & $\mathrm{Cm}^{\mathrm{R}}$ & 3.0 & 1965 \\
\hline pSK 74 & SK 1064 & $\mathrm{Pc}^{\mathrm{R}} \mathrm{Asa}^{\mathrm{R}} \mathrm{Asi}^{\mathrm{R}} \mathrm{Cd}^{\mathrm{R}} \mathrm{Hg}^{\mathrm{R}}$ & 21.7 & 1953 \\
\hline pSK 75 & SK 1073 & $\mathrm{Pc}^{\mathrm{R}} \mathrm{Asa}{ }^{\mathrm{R}} \mathrm{Asi}^{\mathrm{R}} \mathrm{Cd}^{\mathrm{R}} \mathrm{Hg}_{\mathrm{D}}^{\mathrm{R}}$ & $21 \cdot 5$ & 1951 \\
\hline pSK 76 & SK 1373 & $\mathrm{Pc}^{\mathrm{R}} \mathrm{Asa} \mathrm{R}_{\mathrm{Asi}}^{\mathrm{R}} \mathrm{Cd}^{\mathrm{R}} \mathrm{Hg}^{\mathrm{R}}$ & $15 \cdot 1$ & 1960 \\
\hline pSK 77 & SK 1499 & $\mathrm{Pc}^{\mathrm{R}} \mathrm{Cd}^{\mathrm{R}}$ & 17.5 & 1965 \\
\hline pSK79 & SK 1215 & $\mathrm{Pc}^{\mathrm{R}} \mathrm{Asa}{ }^{\mathrm{R}} \mathrm{Asi}^{\mathrm{R}} \mathrm{Cd}^{\mathrm{R}} \mathrm{Hg}^{\mathrm{R}}$ & $24 \cdot 7$ & 1953 \\
\hline pSK80 & SK 1529 & $\mathrm{Pc}^{\mathrm{R}} \mathrm{Asa} \mathrm{R}_{A s i}{ }^{\mathrm{R}} \mathrm{Cd}^{\mathrm{R}} \mathrm{Hg}^{\mathrm{R}}$ & 20.8 & 1965 \\
\hline
\end{tabular}

Abbreviations as in tables I and II. 
pSK77 (SK1499; fig. 1, lane j) encode resistance only to penicillin and to the heavy metal cadmium.

Digestion of these heavy metal-resistance plasmids with EcoRI, revealed a close relatedness between pSK60, pSK64, pSK 75, pSK79, pSK 74, pSK59 and pSK80 (fig. 2, lanes b-h); each possessed common EcoRI fragments of $6 \cdot 6,2 \cdot 5,2 \cdot 3$ and $1 \cdot 0 \mathrm{~kb}$. On this basis, these plasmids were assigned to the $\alpha$ family of penicillinase plasmids, as described by Shalita, Murphy and Novick (1980). Of similar phenotype, pSK 76 (fig. 2, lane i) belongs to the $\gamma$ family since it lacks the 2.5 and $1.0 \mathrm{~kb} E c o$ RI fragments (Shalita et al., 1980). The remaining penicillinase plasmids pSK 77 and pSK67 (fig. 2, lanes j and k) appear unrelated to either of these families and resemble members of the 'orphan'

\section{$a b c d e f g h i j k$}

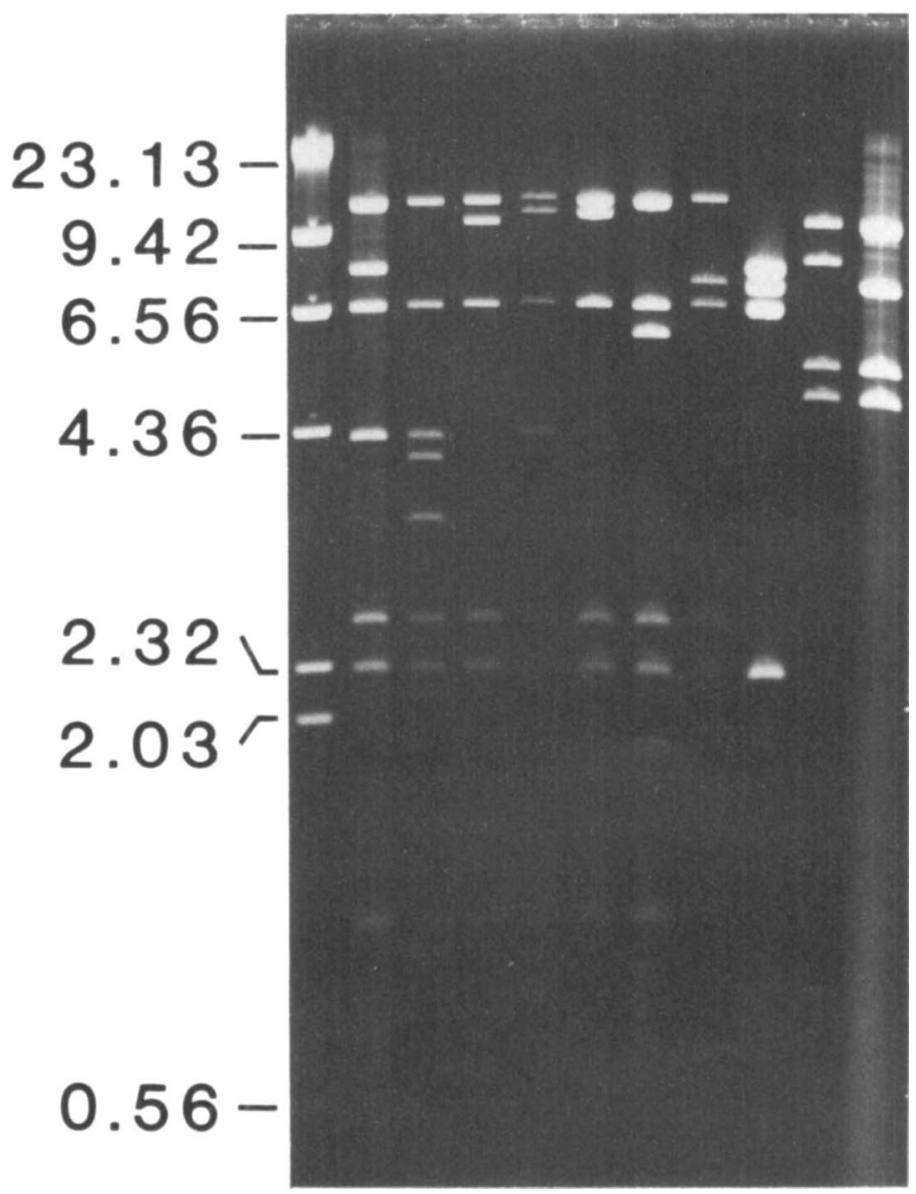

FIG. 2.-Agarose gel $(1.0 \% \mathrm{w} / \mathrm{v})$ electrophoresis of purified $S$. aureus heavy metal resistance- and penicillinase-plasmid DNA cleaved with the restriction endonuclease EcoRI. Lanes contain: (a) lambda phage DNA cleaved with Hind III; (fragment sizes in kilobases (kb) taken from Daniels et al., 1983 are shown on the left); (b) pSK60; (c) pSK64; (d) pSK75; (e) pSK 79; (f) pSK 74; (g) pSK 59; (h) pSK80; (i) pSK 76; (j) pSK 77; and (k) pSK67. Properties of these plasmids are presented in table III. 
family of penicillinase plasmids which, like pSK 67 and pSK 77, mediate resistance only to penicillin and cadmium (Shalita et al., 1980).

Tetracycline resistance $\left(\mathrm{Tc}^{\mathrm{R}}\right)$ in the isolates SK 1215, SK 1373, SK 1396 and SK 1592 (fig. 1, lanes $\mathrm{f}, \mathrm{h}, \mathrm{i}$ and $\mathrm{q}$ ) was shown by mixed culture transfer and restriction endonuclease analysis to be mediated by a common $2.8 \times 10^{6} \mathrm{~mol}$. wt plasmid, pSK 52 . The presence of this plasmid was inferred in the $\mathrm{Tc}^{\mathrm{R}}$ isolate SK1529 (fig. 1, lane k) which possesses extrachromosomal DNA of the same mol. wt, although the $\mathrm{Tc}^{\mathrm{R}}$ phenotype could not be transferred or eliminated from this strain. On the basis of restriction endonuclease fingerprinting with $\mathrm{Hind}$ III and $\mathrm{MboI}$, which generate three and four fragments, respectively, the $\mathrm{Tc}^{\mathrm{R}}$-plasmid pSK 52 (fig. 3A, lanes $\mathrm{b}$ and d) was found to be indistinguishable from pT181 (fig. 3A, lanes a and c), a S. aureus tetracycline resistance plasmid of known nucleotide sequence (Khan and Novick, 1983). The $\mathrm{Tc}^{\mathrm{R}}$ isolates SK 1585 , SK 1582, SK 462 and SK 460 (fig. 1, lanes 1, m, o and p) did not contain pSK52, and $\mathrm{Tc}^{\mathrm{R}}$ could not be associated with plasmid DNA of a different mol. wt; therefore, in these strains, $\mathrm{Tc}^{\mathrm{R}}$ was assumed to be chromosomally encoded.

Chloramphenicol resistance $\left(\mathrm{Cm}^{\mathrm{R}}\right)$ was found to be mediated by plasmids of approximately $3 \times 10^{6} \mathrm{~mol}$. wt, such as pSK2, pSK68, pSK 70 and pSK 71 (fig. 1, lanes $o, q, g$ and $\mathrm{i}$ ), which were distinguished on the basis of restriction endonuclease analysis (M. Gillespie, J. May and R. Skurray, unpublished data). The $\mathrm{Cm}^{\mathrm{R}}$-plasmid pSK68 also specified streptomycin resistance $\left(\mathrm{Sm}^{\mathrm{R}}\right)$ and was the only plasmid encountered to which $\mathrm{Sm}^{\mathrm{R}}$ could be assigned. The $\mathrm{Sm}^{\mathrm{R}}$ isolate $\mathrm{SK} 1373$ (fig. 1, lane h) possessed only the penicillinase plasmid pSK 76 and the $\mathrm{Tc}^{\mathrm{R}}$-plasmid pSK 52; plasmid free derivatives of this strain retained $\mathrm{Sm}^{\mathrm{R}}$, suggesting chromosomal encodement of this determinant. Similar results obtained with other strains are in accord with a chromosomal locus for this determinant.

Erythromycin resistance $\left(\mathrm{Em}^{\mathrm{R}}\right)$ in SK1396 (fig. 1, lane i) was mediated by the $2 \cdot 4 \times 10^{6}$ mol. wt plasmid pSK61. This plasmid was compared with $\mathrm{pE} 194$, an $\mathrm{Em}^{\mathrm{R}}$ plasmid of similar mol. wt, the nucleotide sequence of which is known (Horinouchi and Weisblum, 1982). Digestion of both plasmids with $\mathrm{MboI}$ and TaqI showed that pSK61 (fig. 3B, lanes $\mathrm{c}$ and e) differs from $\mathrm{pE} 194$ (fig. 3B, lanes $\mathrm{b}$ and d). Other $\mathrm{Em}^{\mathrm{R}}$ isolates, such as SK1529, SK 1585, SK 1582, SK462 and SK 460 (fig. 1, lanes k, 1, m, o and p) did not possess extrachromosomal DNA of this mol. wt and no association of this phenotype could be made with any plasmids in these strains. The finding that $\mathrm{Em}^{\mathrm{R}}$ transcipients from mixed culture transfer experiments between SK 1529 and SK 982 lacked extrachromosomal DNA provides support for a chromosomal locus for this determinant as has previously been suggested with other Melbourne isolates (Lyon et al., 1983; Gillespie et al., 1984).

$\mathrm{KN}^{\mathrm{R}}$ strains isolated in 1965 were of phage type $84 / 85$ at RTD and showed a plasmid-DNA profile similar to the $\mathrm{KN}^{\mathrm{S}}$ isolate SK1529 (fig. 1, lane k), which possessed penicillinase, $\mathrm{Tc}^{\mathrm{R}}$ and cryptic $\left(1 \times 10^{6} \mathrm{~mol}\right.$. wt $)$ plasmids. Resistance to these aminoglycosides could not be associated with any plasmid in these strains nor in subsequent $\mathrm{KN}^{\mathrm{R}}$ isolates. In contrast, TKN ${ }^{\mathrm{R}}$ isolates, such as SK 1499 and SK1597 (fig. 1, lanes $\mathrm{j}$ and $\mathrm{n}$ ) carry a $3 \times 10^{6}$ mol. wt plasmid which encodes this resistance phenotype; this plasmid in the latter strain is designated pSK50 and its identity to the plasmid seen in SK 1499 is yet to be established.

In the 1976 gentamicin-resistant isolates as first described by Perceval, McLean and 
A

$a b c d e$

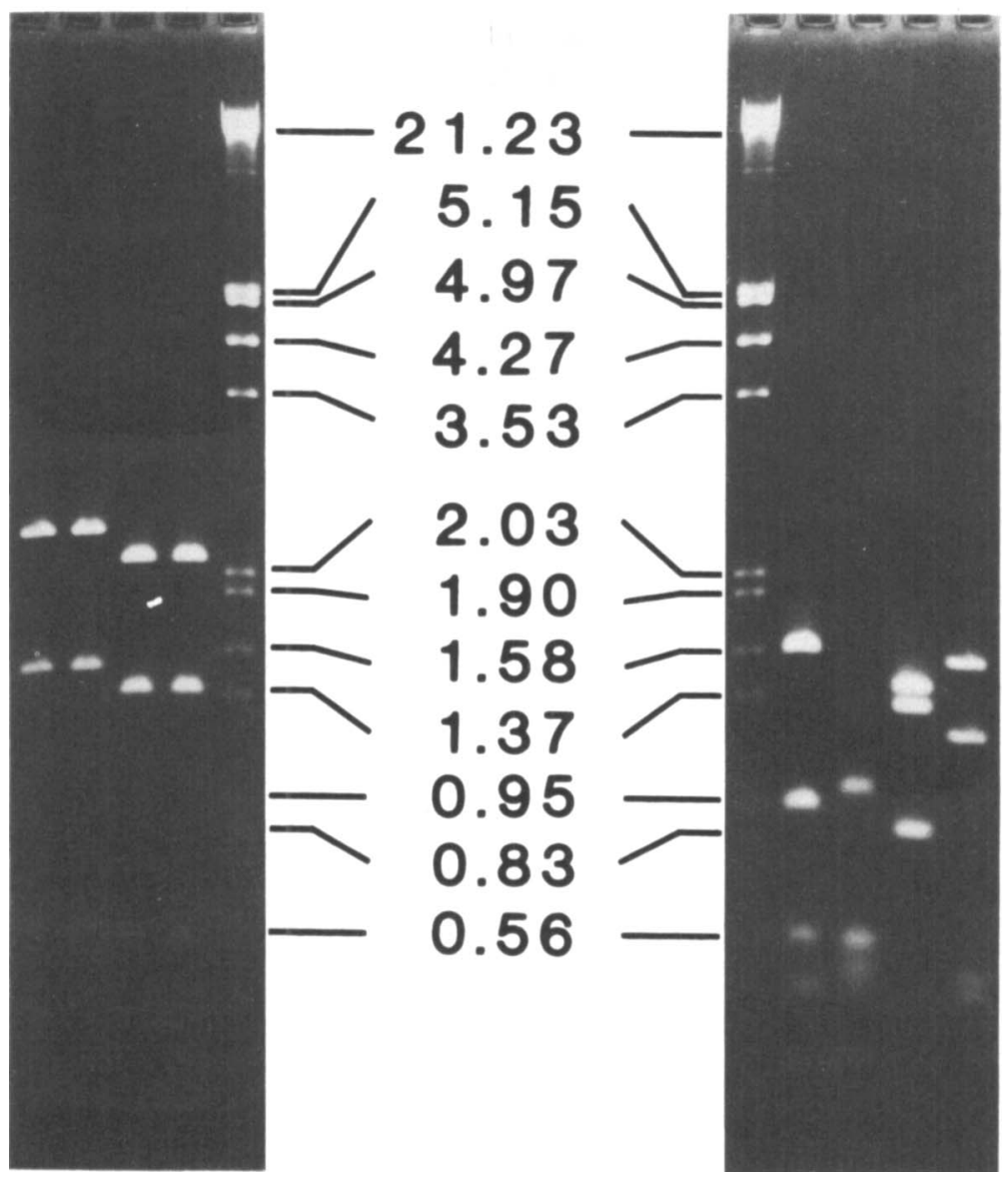

FIG. 3.-A. Agarose gel $(1.2 \% \mathrm{w} / \mathrm{v})$ electrophoresis of tetracycline-resistance plasmids from $S$. aureus. Lanes contain: (a) and (c) pT181; (b) and (d) pSK 52; (e) lambda phage DNA cleaved with EcoRI and Hind III with fragment sizes in kb taken from Daniels et al. (1983) shown on the right. Lanes a and b contain Hind III digested DNA, whereas lanes $\mathrm{c}$ and d contain DNA digested with Mbol. B. Agarose gel $(1 \cdot 2 \%$ w/v) electrophoresis of erythromycin-resistance plasmids from $S$. aureus. Lanes contain: (a) lambda phage DNA cleaved with EcoRI and Hind III with fragment sizes in kb shown on the left; (b) and (d) pE194; (c) and (e) pSK61. Lanes b and c contain MboI digested DNA; lanes d and e contain DNA digested with TaqI.

Wellington (1976), such as SK 1582 (fig. 1, lane m), low-level gentamicin resistance was found to be chromosomally determined, as was the high-level gentamicin resistance of strain SK460 (fig. 1, lane p and Lyon et al., 1984a). However, strain SK462 (fig. 1, lane o) possesses the plasmid pSK 1 which mediates the low-level GTK ${ }^{\mathrm{R}}$ phenotype (Lyon et al., 1983) in this strain as well as resistance to ethidium bromide (Eb) and to quaternary ammonium compounds (Qa), such as benzalkonium chloride and cetyltrimethylammonium bromide (Lyon et al., 1984b). The plasmid pSK 7 present in strain SK460 (fig. 
1 , lane $\mathrm{p}$ ) is related to $\mathrm{pSK} 1$ (Lyon et al., 1984a) and encodes resistance to quaternary ammonium compounds and to ethidium bromide but not to gentamicin (B. Lyon, J. May and R. Skurray, unpublished data); gentamicin-resistant strains from 1976 (e.g. SK1582, fig. 1, lane m) which lack pSK1, pSK 7 or other related plasmids (Lyon et al., 1984a) were susceptible to Eb and Qa.

No antibiotic resistance phenotype could be ascribed to the plasmids smaller than $1.8 \times 10^{6}$ mol. wt in the isolates SK 1020, SK 1215, SK 1064, SK 1396, SK 1529, SK 1585, SK1582, SK1597, SK462 and SK 460 (fig. 1, lanes c, f, g, i, k, l, m, n, o and p).

\section{Discussion}

The $S$. aureus isolates collected from this Melbourne Hospital, resemble strains recovered during the equivalent period from the Royal Prince Alfred Hospital, Sydney with respect to antibiotic resistance and bacteriophage type (Rountree et al., 1951; Rountree, 1953 and 1978; Rountree and Beard, 1958 and 1965; Rountree and Vickery, 1973). At both hospitals, penicillin-resistant strains of various bacteriophage types were detected in the late 1940s. In Melbourne strains, penicillin resistance was mediated by one of two plasmids distinguishable by resistance to arsenate, arsenite and mercury and EcoRI restriction endonuclease patterns. These two plasmids, pSK60 and pSK67, belong to the $\alpha$ and 'orphan' families of penicillinase plasmids, respectively. One further type of penicillinase plasmid, pSK 76, detected in the bacteriophage type $80 / 81$ isolate SK 1373 , belongs to the $\gamma$ family; an association of $\gamma$ family penicillinase plasmids and strains of bacteriophage type $80 / 81$ has been previously reported (Shalita et al., 1980).

Before the early 1970s, penicillinase production, in association with heavy metal resistance, was mediated most commonly by closely related plasmids belonging to the $\alpha$ family. In strains isolated thereafter, the majority of which were methicillin-resistant, penicillinase production and resistance to cadmium and mercury were chromosomally encoded. These observations are similar to those made with methicillin-resistant strains from another Melbourne hospital (Gillespie et al., 1984 and unpublished data). Likewise, tetracycline resistance, which had exclusively been plasmid-mediated since its detection in 1951, was chromosomally determined in the majority of isolates during the 1970s and 1980s. These results, coupled with changes in bacteriophage type from extended group-III lytic patterns evident in the 1960s to limited group III lytic patterns or non-typable reactions in the 1970 s, suggest that isolates from the 1970 s were new endemic hospital strains.

By 1950 , chloramphenicol was widely used clinically and had become accepted as a promising broad spectrum antibiotic (Shaw, 1983); however, $\mathrm{Cm}^{\mathrm{R}} S$. aureus were first noted at this Melbourne hospital late in 1951. In these, and subsequent isolates, $\mathrm{Cm}^{\mathrm{R}}$ was mediated by a variety of plasmids of $3 \times 10^{6} \mathrm{~mol}$. wt. In this respect, the $\mathrm{Cm}^{\mathrm{R}}$ determinant, which persisted on a plasmid, is unlike the determinants for resistance to tetracycline, penicillin and heavy metals all of which altered with time in their locality of encodement from plasmid to chromosome.

Erythromycin-resistant $S$. aureus were noted at this hospital during the early 1960 s. In these strains, resistance was found to be encoded either on a $2.4 \times 10^{6} \mathrm{~mol}$. wt plasmid distinguishable from pE194 (Horinouchi and Weisblum, 1982) or on the chromosome. In the latter strains, $\mathrm{Em}^{\mathrm{R}}$ may be encoded on a transposon, such as 
Tn554, which preferentially occupies a chromosomal site (Novick et al., 1981); the transfer of chromosomally encoded $\mathrm{Em}^{\mathrm{R}}$ during mixed culture with strain SK1529 could well be accounted for by transposition of such an element.

Neomycin was used as a prophylatic agent against staphylococcal infection during the late 1950 s and early 1960 s in Australian hospitals and resistance to this antibiotic, by strains of bacteriophage type $84 / 85$, was detected at the Royal Prince Alfred Hospital, Sydney in 1965 (Rountree and Beard, 1965). Strains of this bacteriophage type which were resistant to neomycin and kanamycin were also among isolates collected from this hospital in 1965, although it should be noted that $\mathrm{KN}^{\mathrm{S}}$ strains of the same bacteriophage type were detected (Willis, Smith and O'Connor, 1966; M. Gillespie, J. May and R. Skurray, unpublished data). The $\mathrm{KN}^{\mathrm{R}}$ phenotype in strains throughout this study was chromosomally determined. In contrast, linked resistance to tobramycin, kanamycin and neomycin was mediated by a plasmid such as pSK 50 . The level of resistance that this plasmid confers is equivalent to that of a previously described $S$. aureus plasmid of similar size which encodes a nucleotidyltransferase (Le Goffic et al., 1976).

Low-level gentamicin resistance was found to be chromosomally determined in 1976 isolates but to be mediated by the plasmid pSK1 in the isolates from 1981. The determinant for gentamicin resistance on this plasmid has been shown to be a transposable element, designated Tn4001; additionally this plasmid carries determinants for resistance to ethidium bromide and to quaternary ammonium compounds (Lyon et al., 1984b). If the chromosomal low-level gentamicin resistance seen in the 1976 isolates was due to $\mathrm{Tn} 4001$, this may have transposed to a $\mathrm{Qa}^{\mathrm{R}} \mathrm{Eb}^{\mathrm{R}}$-plasmid, such as pSK7, allowing more rapid dissemination of gentamicin resistance. Strains possessing such a gentamicin- and quaternary ammonium-resistance plasmid may be endowed with a survival advantage over $\mathrm{Qa}^{\mathrm{S}}$ isolates (Townsend et al., 1983b). Such an assumption would explain the high frequency with which pSK 1 and related plasmids have been encountered in Australian strains (Lyon et al., 1984a).

Future studies with the strains described in this paper, and with those in a collection of methicillin-resistant $S$. aureus we have recently described (Gillespie et al., 1984), should provide further insights into the molecular mechanisms whereby resistance determinants have been progressively sequestered by $S$. aureus over a period of four decades so enabling these organisms to persist as important nosocomial pathogens in environments of high antibiotic usage.

We are indebted to J. Spicer, A. Perceval and the staff of the Alfred Hospital, Melbourne for providing cultures of $S$. aureus. We also thank Jannette Iuorio, Anastasios Xidas and Barbara Skipworth for technical assistance and maintenance of strains, and Jan Tennent and Bruce Lyon for useful discussions. This work was supported by a Project Grant from the National Health and Medical Research Council (Australia). MTG is a recipient of a Commonwealth Postgraduate Research Award.

\section{REFERENCES}

Daniels D L, Schroeder J L, Szybalski W, Sanger F, Blattner F R 1983 A molecular map of coliphage lambda. In: Hendrix R W, Roberts J W, Stahl F W, Weisberg R A (eds) Lambda II, Cold Spring Harbor Laboratory, New York, p 469-517.

Gillespie M T, May J W, Skurray R A 1984 Antibiotic susceptibilities and plasmid profiles of nosocomial methicillin-resistant Staphylococcus aureus: a retrospective study. Journal of Medical Microbiology 17:295-310. 
Horinouchi S, Weisblum B 1982 Nucleotide sequence and functional map of $\mathrm{pE} 194$, a plasmid that specifies inducible resistance to macrolide, lincosamide, and streptogramin type $B$ antibiotics. Journal of Bacteriology 150:804-814.

Khan S A, Novick R P 1983 Complete nucleotide sequence of pT181, a tetracycline-resistance plasmid from Staphylococcus aureus. Plasmid 10:251-259.

Le Goffic F, Martel A, Capmau M L, Baca B, Goebel P, Chardon H, Soussy C J, Duval J, Bouanchaud D H 1976 New plasmid-mediated nucleotidylation of aminoglycoside antibiotics in Staphylococcus aureus. Antimicrobial Agents and Chemotherapy 10:258-264.

Lyon B R, Iuorio J L, May J W, Skurray R A 1984a Molecular epidemiology of multiresistant Staphylococcus aureus in Australian hospitals. Journal of Medical Microbiology 17:79-89.

Lyon B R, May J W, Skurray R A 1983 Analysis of plasmids in nosocomial strains of multiple-antibiotic-resistant Staphylococcus aureus. Antimicrobial Agents and Chemotherapy 23:817-826.

Lyon B R, May J W, Skurray R A $1984 b$ Tn 4001 : a gentamicin and kanamycin resistance transposon in Staphylococcus aureus. Molecular and General Genetics 193:554-556.

McDonnell R W, Sweeney H M, Cohen S 1983 Conjugational transfer of gentamicin resistance plasmids intra- and interspecifically in Staphylococcus aureus and Staphylococcus epidermidis. Antimicrobial Agents and Chemotherapy 23:151-160.

Novick R P, Khan S A, Murphy E, Iordanescu S, Edelman I, Krolewski J, Rush M 1981 Hitchhiking transposons and other mobile genetic elements and site-specific recombination systems in Staphylococcus aureus. In: Cold Spring Harbor Symposia on Quantitative Biology, Vol XLV, Cold Spring Harbor Laboratory, pp 67-76.

Novick R, Sanchez-Rivas C, Gruss A, Edelman I 1980 Involvement of the cell envelope in plasmid maintenance: plasmid curing during the regeneration of protoplasts. Plasmid 3:348-358.

Pavillard R, Harvey K, Douglas D, Hewstone A, Andrew J, Collopy B, Asche V, Carson P, Davidson A, Gilbert G, Spicer J, Tosolini F 1982 Epidemic of hospital-acquired infection due to methicillin-resistant Staphylococcus aureus in major Victorian hospitals. Medical Journal of Australia 1:451-454.

Perceval A, McLean A J, Wellington C V 1976 Emergence of gentamicin resistance in Staphylococcus aureus. Medical Journal of Australia 2:74.

Rountree P M 1953 Bacteriophage typing of strains of staphylococci isolated in Australia. Lancet 1:514-516.

Rountree P M 1978 History of staphylococcal infection in Australia. Medical Journal of Australia 2:543-546.

Rountree P M, Barbour R G H, Thomson E F 1951 Incidence of penicillin-resistant and streptomycin-resistant staphylococci in a hospital. Lancet 1:435-436.

Rountree P M, Beard M A 1958 Further observations on infection with phage type 80 staphylococci in Australia. Medical Journal of Australia 2:789-795.

Rountree P M, Beard M A 1965 The spread of neomycin-resistant staphylococci in a hospital. Medical Journal of Australia 1:498-502.

Rountree P M, Vickery A M 1973 Further observations on methicillin-resistant staphylococci. Medical Journal of Australia 1:1030-1034.

Shalita Z, Murphy E, Novick R P 1980 Penicillinase plasmids of Staphylococcus aureus: structural and evolutionary relationships. Plasmid 3:291-311.

Shaw W V 1983 Chloramphenicol acetyltransferase: enzymology and molecular biology. CRC Critical Reviews in Biochemistry 14:1-46.

Tennent J M, May J W, Skurray R A 1984 Multiple antibiotic resistance in Staphylococcus aureus and Staphylococcus epidermidis: plasmids in strains associated with nosocomial infection. Pathology 16:250-255..

Townsend D E, Grubb W B, Ashdown N $1983 a$ Gentamicin resistance in methicillin-resistant Staphylococcus aureus. Pathology 15:169-174.

Townsend D E, Greed L, Ashdown N, Grubb W B $1983 b$ Plasmid-mediated resistance to quaternary ammonium compounds in methicillin-resistant Staphylococcus aureus. Medical Journal of Australia 2:310.

Willis A T, Smith J A, O'Connor J J 1966 Properties of some epidemic strains of Staphylococcus aureus. Journal of Pathology and Bacteriology 92:345-358. 